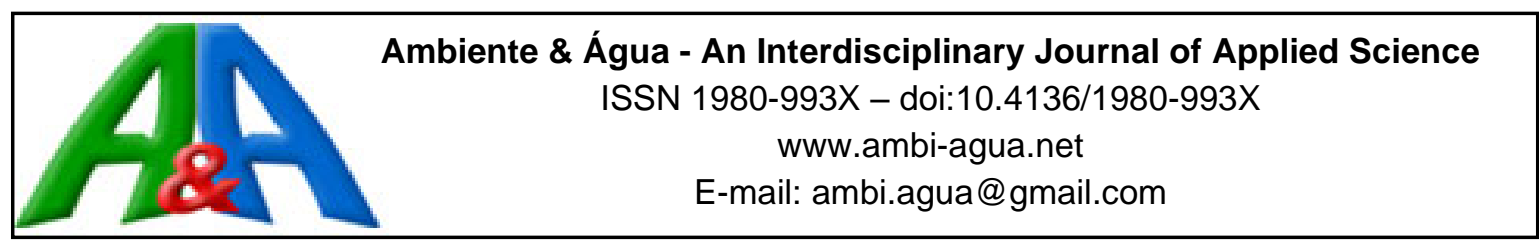

\title{
Control charts for monitoring drip irrigation with different hydraulic heads
}

\author{
ARTICLES doi:10.4136/ambi-agua.2554
}

Received: 03 Apr. 2020; Accepted: 04 Jun. 2020

\section{Allan Remor Lopes ${ }^{*}{ }^{*}$; ;arcio Antonio Vilas Boas ${ }^{1(\mathbb{D})}$; Felix Augusto Pazuch ${ }^{1}$ (D); Diane Aparecida Ostroski2 ${ }^{\circledR}$; Marta Juliana Schmatz ${ }^{1}$ D}

\footnotetext{
${ }^{1}$ Centro de Ciências Exatas e Tecnológicas. Programa de Pós-Graduação em Engenharia Agrícola. Departamento de Recursos Hídricos e Saneamento Ambiental. Universidade Estadual do Oeste do Paraná (UNIOESTE), Rua Universitária, n 2069, CEP: 85819-110, Cascavel, PR, Brazil. E-mail: marcio.vilasboas@unioeste.br, felix_pazuch@hotmail.com,julischmatz@hotmail.com ${ }^{2}$ Coordenação de Engenharia Civil. Universidade Tecnológica Federal do Paraná (UTFPR), Rua Cristo Rei, n 19, Cep: 85902-490, Toledo, PR, Brazil. E-mail: dianeostroski@gmail.com *Corresponding author. E-mail: allanremorlopes@gmail.com
}

\begin{abstract}
This study monitored a drip irrigation system with different hydraulic heads, using control charts. The study included 25 tests, and was conducted at the Experimental Nucleus of Agricultural Engineering of the State University of Western Paraná, located in the municipality of Cascavel, Paraná. The drip irrigation system was operated by gravity, and had four hydraulic heads $(10,11,12$ and $15 \mathrm{kPa})$. The uniformity of the system was determined based on uniformity distribution. Uniformity monitoring was performed using Shewhart and exponentially weighted moving-average (EWMA) control charts. An increase in the hydraulic head increased uniformity. The use of 12 and $15 \mathrm{kPa}$ hydraulic heads yielded good performance, whereas 10 and $11 \mathrm{kPa}$ yielded regular performance. The use of control charts proved to be efficient; the Shewhart control chart was more robust, whereas the EWMA control chart, which indicated trends and deviations not shown by Shewhart control charts, was more sensitive.
\end{abstract}

Keywords: EWMA control chart, micro irrigation, Shewhart control chart, uniformity.

\section{Gráficos de controle no monitoramento da irrigação por gotejamento com diferentes cargas hidráulicas}

\section{RESUMO}

Nesse estudo, um sistema de irrigação por gotejamento com diferentes cargas hidráulicas foi monitorado por gráficos de controle. Este experimento foi conduzido no Núcleo Experimental de Engenharia Agrícola da Universidade Estadual do Oeste do Paraná, localizado no município de Cascavel, Paraná. Neste estudo, o sistema de irrigação por gotejamento foi conduzido por gravidade, com 4 cargas hidráulicas (10, 11, 12 e $15 \mathrm{kPa}) ; 25$ ensaios foram realizados para cada carga hidráulica. Além disso, sua uniformidade foi determinada pelo coeficiente de uniformidade de distribuição. O monitoramento da sua uniformidade foi realizado pelos gráficos de controle de Shewhart e da Média Móvel Exponencialmente Ponderada (MMEP). O aumento da carga hidráulica aumentou a uniformidade de distribuição. $\mathrm{O}$ uso das cargas hidráulicas de 12 e $15 \mathrm{kPa}$ obtiveram uma boa uniformidade, enquanto que as 
cargas hidráulicas de 10 e $11 \mathrm{kPa}$ produziram uma uniformidade regular. A utilização dos gráficos de controle mostrou ser eficiente, o gráfico de controle de Shewhart demonstrou ser mais robusto, enquanto que o gráfico de controle MMEP, indicou tendências e desvios não apresentados pelo gráfico de controle de Shewhart, sendo mais sensível.

Palavras-chave: gráfico de controle MMEP, gráfico de controle Shewhart uniformidade, microirrigação.

\section{INTRODUCTION}

Drip irrigation requires high investment in construction and equipment for water collection, conduction, control and distribution, in addition to energy and labor costs (Da Silva et al., 2003). Hence, the use of drip irrigation is limited for small rural producers who do not have the required financial resources.

One technique that reduces the initial cost and the variable cost of drip irrigation is gravity irrigation. In this technique, reservoirs are raised to a minimum height of $1 \mathrm{~m}$ for the supply of water in small areas, thus eliminating the use of hydraulic pumps (Souza et al., 2009). The possibility of performing drip irrigation without electricity and the low cost of the dripper make this tool more attractive, as it can contribute to the development of small rural producers.

One of the main parameters used in the evaluation of drip irrigation systems is the uniformity of water application over the irrigated area (De Souza et al., 2006). Uniformity characterizes an irrigation system based on the difference in water volume applied by emitters and directly affects irrigation management, efficiency, cost, as well as crop quality and productivity (Azevedo and Saad, 2012). Further, irrigation control prevents physiological and phytosanitary problems, thus reducing unnecessary losses of water, energy and nutrients (Trevisan et al., 2016).

Control charts are most frequently used to monitor the performance of processes over time (Vieira, 2014). A control chart is a graphic representation of sample measurements of a given process and indicates the need to investigate and adjust a process according to the size of deviations presented.

Shewhart's and exponentially weighted moving-average (EWMA) control charts are among the best-known and the most frequently used ones (Frigo et al., 2016). The success of Shewhart's control chart is owing to its simplicity, in which the ease of the decision rule is based only on examining the last observed point. However, this is also a major disadvantage, as any information provided by the previous sequence of points is disregarded, which renders the Shewhart control chart relatively insensitive to minor changes in the process (Walter et al., 2013).

Minor variations in a process cannot be perceived by the Shewhart control chart; in this case, it is advisable to use the EWMA control chart. This control chart is more sensitive in detecting minor deviations from the average of a process. Therefore, such a method offers high speed and credibility in identifying minor mismatches in the process.

Vilas Boas (2016) reported that the use of control charts in irrigation provides several benefits: compliance with irrigation quality standards, monitoring of systematic errors in the irrigation process, provision of information regarding the status of the irrigation process, calculation of measurement uncertainty in irrigation, provision of objective evidence for demonstrating quality of measurements, and provision of a source of historical data on the measurement process in irrigation. Andrade et al. (2017a) concluded that micro irrigation uniformity can be analyzed through control charts.

Irrigation systems are commonly monitored using control charts; however, they are rarely monitored using hydraulic heads. Therefore, this study was conducted to evaluate the 
uniformity of a drip irrigation system with different hydraulic heads through Shewhart and EWMA control charts.

\section{MATERIAL AND METHODS}

The study was performed at the Experimental Nucleus of Agricultural Engineering of the State University of Western Paraná, located in the municipality of Cascavel, Paraná, Brazil, with geographical coordinates of $24^{\circ} 58^{\prime} \mathrm{S}$ and $53^{\circ} 27^{\prime} \mathrm{W}$.

The system consisted of flat drip tubes (SIPLAST ${ }^{\mathrm{TM}}$, Model P1) with a diameter of $16 \mathrm{~mm}$, an inlet filter with an area of $7.5 \mathrm{~mm}^{2}$, and a total of eight holes. There was a $0.20 \mathrm{~m}$ space between the drippers, and potential flow equation $=0.19$. pressure ${ }^{0,52}$. Considering a main line and four lateral lines, the system included 75 drippers per line, thus totaling 300 drippers. To reduce clogging, a 120-mesh screen filter was installed close to the reservoir.

For data collection, the methodology proposed by Keller and Karmeli (1975) was used, which involved determining the flow in four emitters per lateral line; the first dripper, drippers located at $1 / 3$ and $2 / 3$ of the lateral line length and the last dripper in four lateral lines. The system was pressurized by gravity. Figure 1 shows the experimental set-up and the data collection technique.

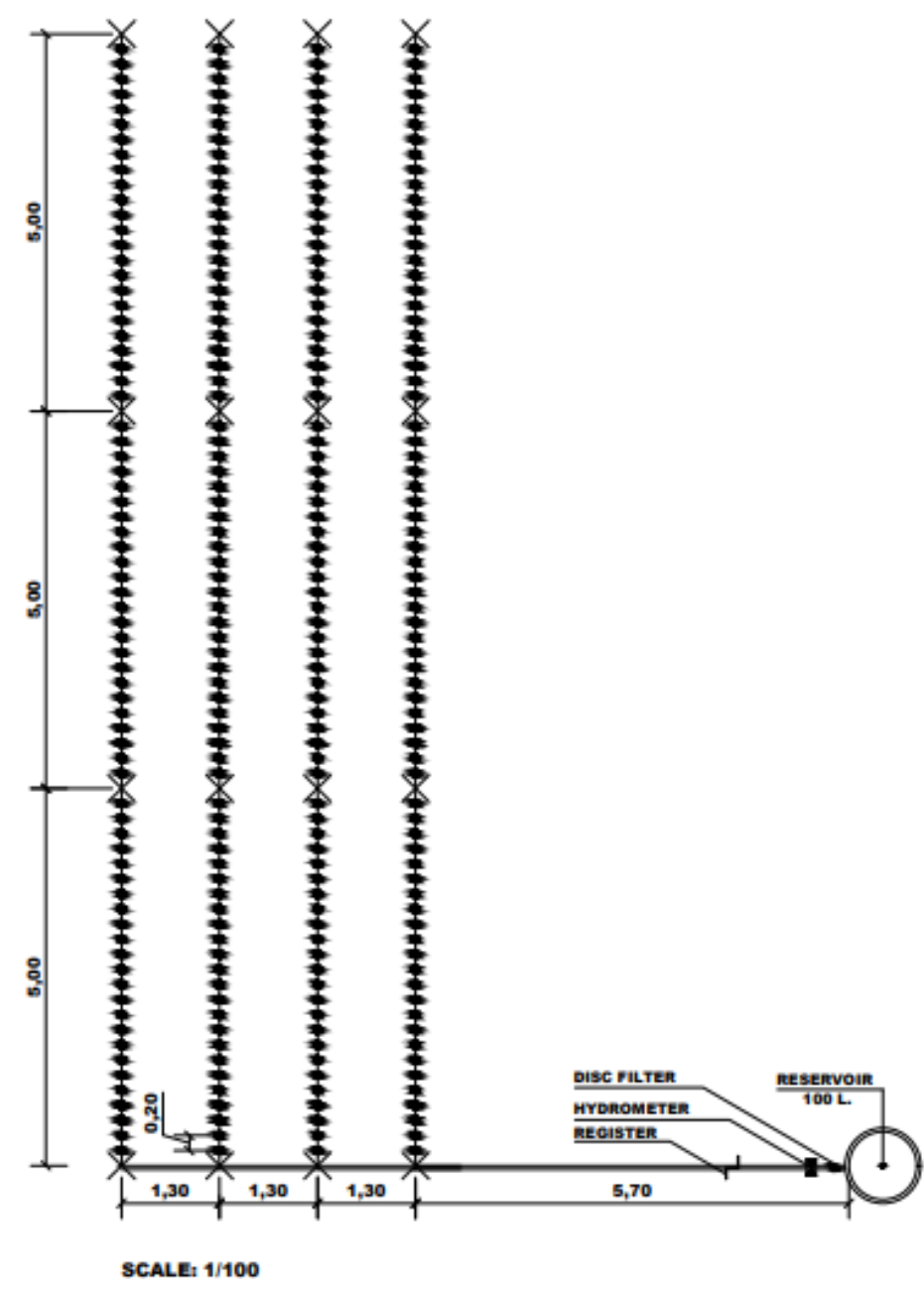

Figure 1. Experimental set-up and data collection technique.

After assembling the system, four different hydraulic heads were evaluated: 10, 11, 12 and $15 \mathrm{kPa}$. A total of 25 tests were performed for each hydraulic head, and the number of samples recommended by Montgomery (2016) for quality control tests was used. Furthermore, a 
descriptive statistic was performed to measure the central tendency.

To assess the uniformity of the irrigation system, the distribution uniformity (UD) proposed by Merrian and Keller (1978) was used, as expressed in Equation 1.

$U D=\left(\frac{Q_{25}}{\overline{\bar{Q}}}\right)$

Where:

UD: uniformity distribution, (\%);

$\mathrm{Q}_{25}$ : average of the $1 / 4$ smaller flow rates of the drippers, $\left(\mathrm{L} \mathrm{h}^{-1}\right)$;

$\overline{\bar{Q}}$ : arithmetic mean of flows $\left(\mathrm{L} \mathrm{h}^{-1}\right)$.

The following classifications were used to classify the UD data, which are listed in Table 1 .

Table 1. UD classification.

\begin{tabular}{cc}
\hline UD & Classification \\
\hline$>90 \%$ & Excellent \\
$80-90 \%$ & Good \\
$70-80 \%$ & Regular \\
$60-70 \%$ & Bad \\
$<60 \%$ & Unacceptable \\
\hline
\end{tabular}

Source: Bernardo et al. (2008).

To monitor UD, a Shewhart control chart was prepared to investigate the parameters during the tests. It is necessary to prepare the control charts to determine the upper control limit (UCL) and lower control limit (LCL) using Equations 2 and 3, respectively.

$$
\begin{aligned}
& U C L=\overline{\bar{X}}+3 \frac{\overline{\overline{A M}}}{d_{2}} \\
& L C L=\overline{\bar{X}}+3 \frac{\overline{\overline{A M}}}{d_{2}}
\end{aligned}
$$

Where:

UCL: upper control limit;

LCL: lower control limit;

$\overline{\bar{X}}$ : data average;

$\overline{\overline{A M}}$ : average of data amplitudes; 2016).

$d_{2}$ : constant equal to 1.128 for $\mathrm{n}=2$, considering individual measures (Montgomery,

In addition to the Shewhart control chart, the EWMA control chart was used, which detected minor variations in behavior and provided a new estimate of the new process average, which might change the desired quality characteristics. This control chart accumulates successive information, weighs the samples, and provides more weight to the most recent information.

The EWMA control chart consisted of plotting $\mathrm{Z} i$ versus sample number i (or time), which 
can be calculated using Equation 4, according to Roberts (1959).

$Z i=u 0=\overline{\bar{X}}$

Where:

$0<\lambda \leq 1$

$\mathrm{Z} i=\mathrm{u} 0=\overline{\bar{X}}$ (target value or mean value in $\mathrm{x}_{\mathrm{i}}$ control).

The variance of the variable $\mathrm{Z}$ is expressed as Equation 5 .

$\sigma_{z i}^{2}=\sigma^{2}\left(\frac{\lambda}{2-\lambda}\right)\left[1-(1-\lambda)^{2 i}\right]$

Where:

$\sigma:$ standard deviation of the data in relation to the mean;

$\lambda$ : weight assigned to each sample;

$i$ : order of sample used.

Roberts (1959) reported that the UCL and the LCL of the EWMA control chart can be calculated by Equations 6 and 7, respectively.

$$
\begin{aligned}
& U C L=\overline{\bar{X}}+\mathrm{L} \sigma \sqrt{\frac{\lambda}{(2-\lambda)}[1-(1-\lambda)]^{z i}} \\
& L C L=\overline{\bar{X}}-\mathrm{L \sigma} \sqrt{\frac{\lambda}{(2-\lambda)}[1-(1-\lambda)]^{z i}}
\end{aligned}
$$

Where:

$\overline{\bar{X}}$ : average of the data;

$\lambda$ : weight assigned to each sample, which varies from 0 to 1 ;

L: number of standard deviations to control the mean to be detected;

$i$ : order of sample used.

In this study, 0.25 is the weight constant of the sample, and for the width of the $\lambda$ limits the factor is $\mathrm{L}=2$.

\section{RESULTS AND DISCUSSION}

An exploratory analysis was performed to provide a general characterization of the irrigation process. Table 2 summarizes the descriptive statistics for UD using different hydraulic heads.

The greatest uniformity was achieved using $15 \mathrm{kPa}$ hydraulic head $(89.91 \%)$, and the 12 $\mathrm{kPa}$ hydraulic head performed relatively well $(87.12 \%)$. However, the $11 \mathrm{kPa}$ hydraulic head indicated a regular uniformity $(79.11 \%)$, whereas the $10 \mathrm{kPa}$ hydraulic head demonstrated the lowest uniformity (77.00\%). Gris et al. (2012) used hydraulic heads measuring 1.5 and $2.0 \mathrm{~m}$ in a drip irrigation system with cassava wastewater and obtained UD values exceeding $90 \%$. Souza et al. (2009) evaluated drip irrigation systems by gravity using microtubes and obtained an average UD value of $87 \%$. 
It is observed that the hydraulic head is proportional to uniformity; the higher the hydraulic head, the greater the uniformity. A situation finding has been discovered by Klein et al. (2013), who used 15, 18 and $20 \mathrm{kPa}$ hydraulic heads in irrigation and fertigation systems, and consistently obtained greater uniformity at $20 \mathrm{kPa}$. According to Hermes et al. (2018), the hydraulic head affects the flow rate during irrigation. The distribution uniformity generally increases with the hydraulic heads (Ella et al., 2009).

Table 2. Exploratory analysis of UD of drip irrigation system tests with different hydraulic heads.

\begin{tabular}{lcccc}
\hline Hydraulic heads & $10 \mathrm{kPa}$ & $11 \mathrm{kPa}$ & $12 \mathrm{kPa}$ & $15 \mathrm{kPa}$ \\
\hline Minimum & 59.69 & 66.95 & 78.51 & 83.66 \\
$\mathrm{Q}_{1}$ & 68.87 & 70.95 & 85.37 & 87.24 \\
Average & 77.00 & 79.11 & 87.12 & 89.81 \\
$\mathrm{Q}_{3}$ & 83.72 & 84.47 & 90.12 & 92.28 \\
Maximum & 89.73 & 89.07 & 91.46 & 95.47 \\
Standard deviation & 8.23 & 7.26 & 3.23 & 3.01 \\
Variance & 67.73 & 52.74 & 10.47 & 9.11 \\
CV $(\%)$ & 10.69 & 9.18 & 3.72 & 3.36 \\
Asymmetry & -0.57 & -0.46 & -0.73 & -0.12 \\
Kurtosis & -0.83 & -1.38 & 0.58 & -0.76 \\
\hline
\end{tabular}

Notes: $\mathrm{Q}_{1}$ : First quartile, $\mathrm{Q}_{3}$ : Third quartile, $\mathrm{CV}$ : Coefficient of variation.

Shewhart control charts for different hydraulic heads are shown in Figure 2. It was observed that the hydraulic head classified as regular in terms of uniformity (10 and $11 \mathrm{kPa})$, presented points outside the control limits, indicating points outside of the statistical control process, whereas the 12 and $15 \mathrm{kPa}$ hydraulic heads, whose uniformity was classified as good, were under statistical control, with no trend or no point was outside the control limits. In the study by Andrade et al. (2017b), although most processes were simple, they were classified as controlled by the Shewhart control chart and considered significant for the evaluation of irrigation. 

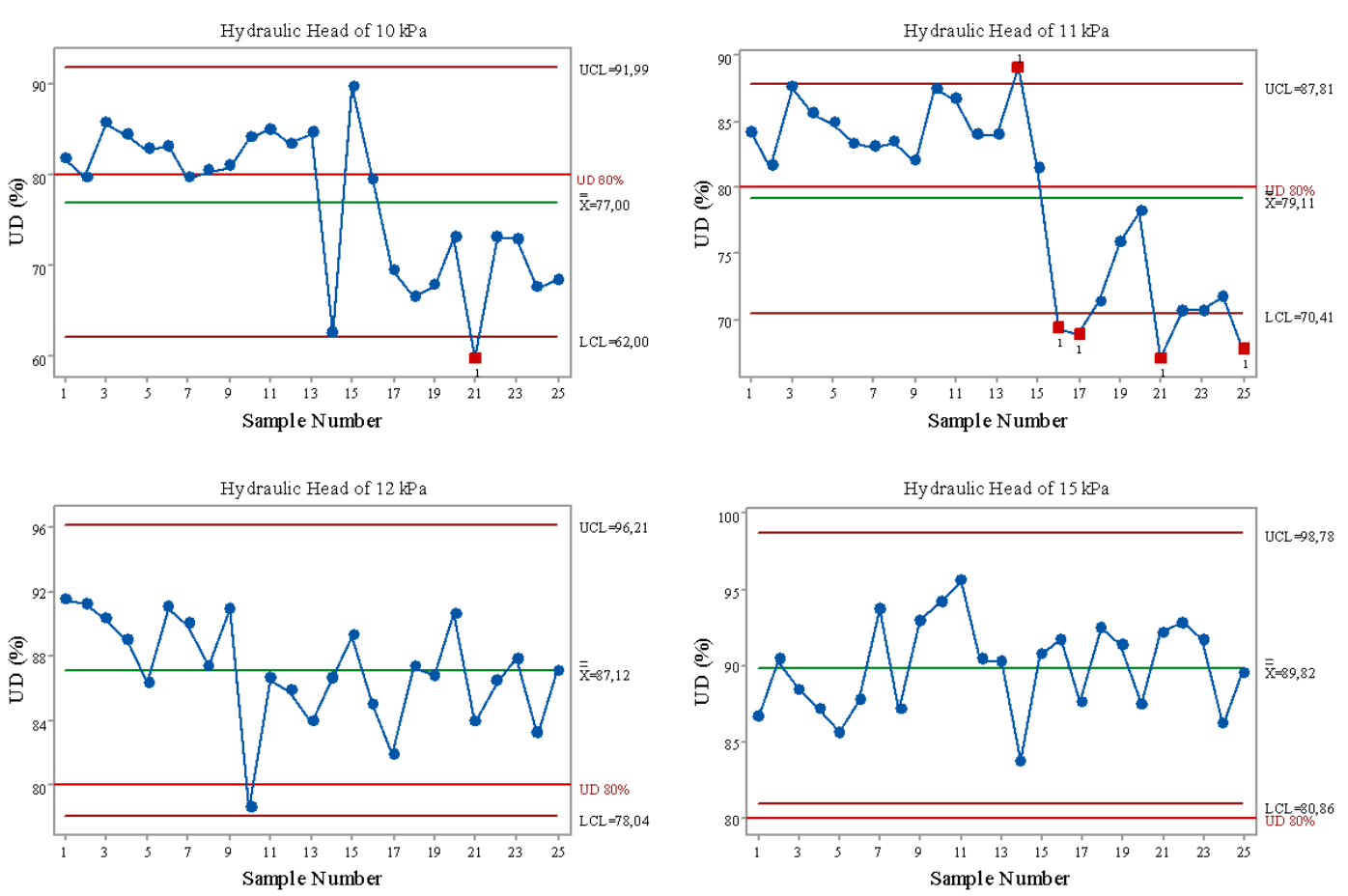

Figure 2. Shewhart's control charts for drip irrigation with different hydraulic heads.

The $10 \mathrm{kPa}$ hydraulic head presented an isolated point outside the control lines, which can be caused by factors such as low pressure (Saraiva et al., 2014), clogging of drippers, energy fluctuations, pressure variations, and climatic factors (Justi and Saizaki, 2016). During the first tests to 10 and $11 \mathrm{kPa}$, the process was under control (1st to 13th tests). Over time, there was a decrease in the quality of process that is attributed to non-controllable factors such as the clogging of emitters, temperature and pressure (Chinchilla et al., 2018).

By analyzing the EWMA control chart for the UD variable (Figure 3), it is evident that the drip irrigation process is out of statistical control, because in addition to presenting points outside the UCL and LCL (10 and $11 \mathrm{kPa}$ ), descending sequences also decreased from the 13th test $(10$ and $11 \mathrm{kPa})$ until the end, characterizing a decrease in the uniformity of the system. Sequences of six points in the descending order characterize an out of statistical control process (Montgomery, 2016). The EWMA control chart is the most suitable for micro irrigation assessment, as it detects minor variations in the process (Siqueira et al., 2018).

The 12 and $15 \mathrm{kPa}$ did not present points outside the control limits. With the increase in the hydraulic head, system pressure, and water speed, the clogging of drippers decreased, and the system uniformity increased (Silva et al., 2017). Consequently, eight consecutive sequences were obtained on the same side of the central line, characterizing the process as out of statistical control (Montgomery, 2016). 

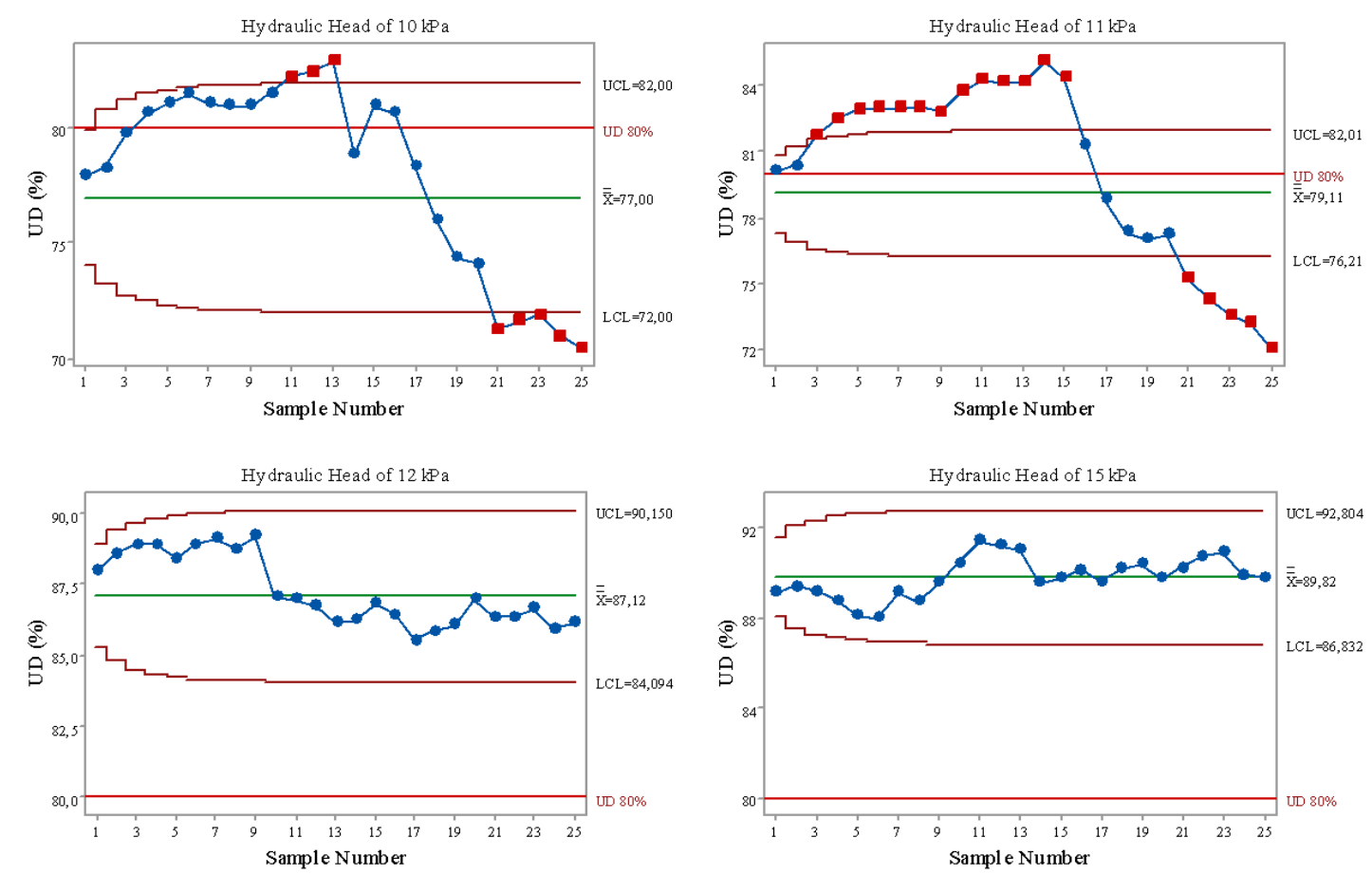

Figure 3. EWMA control charts for drip irrigation with different hydraulic heads.

\section{CONCLUSIONS}

The increase in hydraulic head increased the uniformity of the drip irrigation system. The use of 12 and $15 \mathrm{kPa}$ hydraulic heads demonstrated good performance, with uniformities exceeding $80 \%$, whereas the 10 and $11 \mathrm{kPa}$ hydraulic heads demonstrated regular performance.

The use of control charts was effective in monitoring the system uniformity of drip irrigation based on different hydraulic heads. The Shewhart control chart was more robust, whereas the EWMA control chart, which indicated trends and deviations not shown by the Shewhart control chart, was more sensitive.

In sum, it is recommended that the drip irrigation system by gravity be used, with hydraulic heads greater than $12 \mathrm{kPa}$.

\section{REFERENCES}

ANDRADE, M. G.; VILAS BOAS, M. A.; SIQUEIRA, J. A. C.; DIETER, J.; SATO, M.; HERMES, E.; MERCANTE, E.; TOKURA, L. K. Statistical quality control for the evaluation of the uniformity of micro sprinkler irrigation with photovoltaic solar energy. Renewable and Sustainable Energy Reviews, v. 78, p. 743-753, 2017a. https://doi.org/10.1016/j.rser.2017.05.012

ANDRADE, M. G.; VILAS BOAS, M. A.; SIQUEIRA, J. A. C.; SATO, M.; DIETER, J.; HERMES, E.; MERCANTE, E. Uniformity micro sprinkler irrigation system using statistical quality control. Ciência Rural, v. 47, n. 4, p. 1-7, 2017b. https://doi.org/10.1590/0103-8478cr20160546

AZEVEDO, L. P.; SAAD, J. C. C. Uso de dois espaçamentos entre gotejadores na mesma linha lateral e seus efeitos sobre a formação do bulbo molhado no solo e parâmetros físicos de $\begin{array}{lllllll}\text { rabanete. Irriga, } & \text { v. } 17, \quad \text { n. } & 2, & \text { p. } & 148-167,\end{array}$ https://doi.org/10.15809/irriga.2012v17n2p148 
BERNARDO, S.; SOARES, A. A.; MANTOVANI, E. C. Manual de irrigação. 8. ed. Viçosa: Editora UFV, 2008. 625 p.

CHINCHILLA, S. R. A.; SILVA, E. F. F.; ALMEIDA, C. D. G. C.; SILVA, A. O.; SANTOS, P. R. Statistical process control in the assessment of drip irrigation using wastewater. Engenharia Agrícola, v. 38, n. 1, p. 47-54, 2018. https://doi.org/10.1590/1809-4430eng.agric.v38n1p47-54/2018

DA SILVA, A. L.; FARIA, M. A.; REIS, R. P. Viabilidade técnico-econômica do uso do sistema de irrigação por gotejamento na cultura do cafeeiro. Revista Brasileira de Engenharia Agrícola e Ambiental, v. 7, n. 1, p. 37-44, 2003. https://doi.org/10.1590/S1415-43662003000100007

DE SOUZA, L. O. C.; MANTOVANI, E. C.; SOARES, A. A.; RAMOS, M. M.; DE FREITAS, P. S. L. Avaliação de sistemas de irrigação por gotejamento utilizados na cafeicultura. Revista Brasileira de Engenharia Agrícola e Ambiental, v. 10, n. 3, p. 541-548, 2006. http://dx.doi.org/10.1590/S1415-43662006000300002

ELLA, V. B.; REYES, M. R.; YODER, R. Effect of hydraulic head and slope on water distribution uniformity of a low-cost drip irrigation system. Applied Engineering in Agriculture, v. 25, n. 3, p. 349-356, 2009. https://dx.doi.org/10.13031/2013.26885

FRIGO, J. P.; VILAS BOAS, M. A.; FRIGO, J. P.; FRIGO, E. P. Comparação entre gráficos de controle de Shewhart, Cusum e MMEP no processo de irrigação por aspersão convencional. Irriga, Edição especial, v. 1, n. 1, p. 56-70, 2016. https://doi.org/10.15809/irriga.2016v1n01p56-70

GRIS, D. J.; HERMES, E.; VILAS BOAS, M. A. Aplicação de água residuária de processamento de mandioca em sistema de irrigação por gotejamento. Scientia Agraria Paranaensis, v. 11, p. 1-9, 2012. http://dx.doi.org/10.18188/sap.v11i0.7857

HERMES, E.; VILAS BOAS, M. A.; GONÇALVES, M. P.; GRIS, D. J.; LINS, M. A.; BERGER, J. S. Uniformidade de distribuição na irrigação por gotejamento com água residuária de processamento de mandioca. Revista em Agronegócio e Meio Ambiente, v. 11, n. 2, p. 545-559, 2018. https://doi.org/10.17765/2176-9168.2018v11n2p545-559

JUSTI, A. L.; SAIZAKI, P. M. Desempenho da irrigação e fertirrigação avaliadas por controle estatístico de qualidade. Engenharia na Agricultura, v. 25, n. 6, p. 541-551, 2016.

KELLER, J.; KARMELI, D. Trickle irrigation design. 1. ed. Glendora: Rain Bird Sprinkler Manufacturing Corporation, 1975. 133 p.

KLEIN, M.; SZEKUT, F.; SUSZEK, F.; REIS, C.; AYMORÉ, C.; GUERRA, J.; VILAS BOAS, M. A. Uniformidade de irrigação e fertigação em um sistema de irrigação familiar por gotejamento sob diferentes cargas hidráulicas. Engenharia Ambiental, v. 10, n. 3, p. 56-69, 2013.

MERRIAN, J. L.; KELLER, J. Farm irrigation system evaluation: a guide for management. 1. ed. Logan: Utah State University, 1978. 271 p.

MONTGOMERY, D. C. Introdução ao controle estatístico da qualidade. 7. ed. Rio de Janeiro: LTC, 2016. 549 p.

ROBERTS, S. W. Control chart tests based on geometric moving averages. Technometrics, v. 1, p. 239-250, 1959. https://doi.org/10.1080/00401706.1959.10489860 
SARAIVA, K. R.; REBOUÇAS, R. M.; SOUZA, F. Desempenho de um sistema de irrigação por microaspersão na cultura do coqueiro. Agropecuária Técnica, v. 35, n. 1, p. 62-68, 2014.

SILVA, P. F.; MATOS, R. M.; LIMA, S. C.; DANTAS NETO, J.; LIMA, V. L. A. Obstruction and uniformity in drip irrigation systems by applying treated wastewater. Revista Ceres, v. 64, n. 4, p. 344-350, 2017. https://doi.org/10.1590/0034-737x201764040002

SIQUEIRA, M. M. K.; VILAS BOAS, M. A.; SIQUEIRA, J. A. C.; TOKURA, L. K. Techniques for quality control in football field located in agricultural area. Journal of $\begin{array}{llllllll}\text { Agricultural Science, } & \text { v. } 10, \quad \text { n. } 9, \quad \text { p. 430-442, }\end{array}$ https://dx.doi.org/10.5539/jas.v10n9p430

SOUZA, R. O. R. M.; MIRANDA, E. P.; NASCIMENTO NETO, J. R.; FERREIRA T. T. S.; MESQUITA, F. P. Irrigação localizada por gravidade em comunidades agrícolas do Ceará. Revista Ciência Agronômica, v. 40, n. 1, p. 34-40, 2009.

TREVISAN, P.; MENEGAES, J. F.; FRONZA, D.; NISHIJIMA, T. Produtividade da cultura da figueira (Ficus carica L.) submetida a diferentes estratégias de irrigação por gotejamento. Acta Iguazu, v. 5, n. 2, p. 49-60, 2016.

VIEIRA, S. Estatística para a qualidade. 3. ed. Rio de Janeiro: GEN LTC, 2014, 304 p.

VILAS BOAS, M. A. Fundamentos de irrigação localizada. 1. ed. Cascavel: Edunioeste, 2016. 119 p.

WALTER, O. M. F. C.; HENNING, E.; CARDOSO, M. E.; SAMOHYL, R.W. Aplicação individual e combinada dos gráficos de controle Shewhart e CUSUM: uma aplicação no setor metal mecânico. Gestão \& Produção, v. 20, n. 2, p. 271-286, 2013. https://doi.org/10.1590/S0104-530X2013000200003 